\title{
Yeniliklerin Yayılımı Bağlamında Instagram'da Yapay Zeka Ürünü Sanal Etkileyenin Takipçiler Tarafından Kabulüne Yönelik Bir İnceleme
}

\author{
Sezen Garip (Doktora Öğrencisi) \\ Ege Üniversitesi Sosyal Bilimler Enstitüsü \\ sezengarip24@gmail.com \\ Pelinsu İnceli (Doktora Öğrencisi) \\ (iD) Ege Üniversitesi Sosyal Bilimler Enstitüsü \\ pelinsuinceli@gmail.com \\ Başvuru Tarihi: 01.03.2021 \\ Yayına Kabul Tarihi: 02.06.2021 \\ Yayınlanma Tarihi: 30.07.2021 \\ https://doi.org/10.17680/erciyesiletisim. 888507
}

Öz

Yapay zeka ürünü olan sanal etkileyenlerin artık dijital etkileyenlerin yerini almaya başladığı görülmektedir. Sanal etkileyenlerin dijital etkileyenlerden farkı gerçek olmayan fakat gerçekmiş gibi algılanan kurgulanmış karakterler olmasıdır. Büyük şirketler kar elde etmek için yapay zeka ürünü sanal etkileyenleri, pazarlama aracı veya stratejisi olarak kullanmaktadır. Sanal etkileyenlerin fotoğraf paylaşım ağı olan Instagram'da faaliyet gösterdikleri dikkat çekmektedir. Bu araştırma ise Instagram kullanıcılarının yeniliklerin yayılımı perspektifinde yapay zeka ürünü sanal etkileyeni nasıl algıladığını ele almıștır. Aynı zamanda Instagram kullanıcılarının yaptıkları yorumların yönüne odaklanmıştır. Nitel araştırma kapsamında durum desenine (case study) göre yapılandırılan araștırmada: "Instagram kullanıcıları yapay zeka ürünü sanal etkileyenin paylaşımlarını nasıl algılamaktadır? Yapay zeka ürünü sanal etkileyeni takip eden Instagram kullanıcılarının yaptıkları yorumların yönü nasıldır?" sorularına yanıt aranmıştır. Elde edilen veriler niteliksel ve niceliksel içerik analizi yöntemiyle incelenmiştir. Analiz sonuçlarına göre, Instagram kullanıcılarının yenilik olarak görülen sanal etkileyeni kabullenme eğiliminde oldukları görülmüştür. Aynı zamanda kabullenme eğiliminin satın alma davranışına yönlendirdiği de dikkat çekmiştir.

Anahtar Kelimeler: İletişim, Yapay Zeka, Sanal Etkileyen, Yeniliklerin Yayılımı, Instagram. 


\title{
A Study on the Adoption of the Artificial Intelligence Product Virtual Influencer on Instagram in the Context of the Spread of Innovations by Followers
}

\author{
Sezen Garip (Ph.D. Student) \\ Ege University Institute of Social Sciences \\ sezengarip24@gmail.com \\ Pelinsu İnceli (Ph.D. Student) \\ D Ege University Institute of Social Sciences \\ pelinsuinceli@gmail.com
}

Date Received: 01.03.2021

Date Accepted: 02.06.2021

Date Published: 30.07.2021

https://doi.org/10.17680/erciyesiletisim.888507

\begin{abstract}
Large companies use AI product virtual influencers as a marketing tool to make a profit. It is noteworthy that virtual influencers operate on Instagram, the photo-sharing network. This research discussed how Instagram users perceive the virtual influencer which is created by artificial intelligence in the perspective of the diffusion of innovations. It also focused on the direction of the comments made by Instagram users. The research is structured according to the case study within the scope of qualitative research. The following research questions are addressed in this article: "How do Instagram users perceive the shares of the A.I. virtual influencer? What is the direction of the comments made by Instagram users who follow the A.I. virtual influencer?" The obtained data were analyzed by qualitative and quantitative content analysis methods. According to the results of the analysis, it has been observed that Instagram users tend to accept the virtual influencer seen as an innovation. At the same time, it was noted that the tendency to accept leads to purchasing behavior.
\end{abstract}

Keywords: Communication, Artificial Intelligence, Virtual Influencer, Diffusion of Innovations, Instagram. 


\section{Giriş}

Bilişim teknolojilerindeki gelişmeler, markaların pazarlama stratejilerini yapılandırmalarını zorunlu kılmaktadır. Bu pazarlama stratejilerinin arasında markaların yapay zeka ürünü sanal etkileyenleri kullanması oldukça dikkat çekmektedir. Alanyazın değerlendirildiğinde, insanların bilgi teknolojisiyle nasıl etkileşime girdiklerini inceleyen çalışmaların olduğu görülmektedir. Bu çalışmalarda Instagram kullanıcıları ile sanal etkileyenler arasındaki ilişki kullanıcı yorumları doğrultusunda değerlendirilmiștir. Aynı zamanda bu çalışmalarda, Instagram'ın algoritmik istatistiki bilgilerinden de yararlanılmıştır (Darner \& Arvidsson, 2019; Molin \& Nordgren, 2019).

Konu kapsamında yapılan araştırmaların niceliksel ve niteliksel olarak yeterli olmadığı söylenebilir. Aynı zamanda Türkiye'de yeniliklerin yayılımı çerçevesinde sanal etkileyenleri Instagram kullanıcılarının bakış açıları doğrultusunda ele alan bir çalışmanın olmadığı da dikkat çekmektedir. Dolayısıyla ilgili çalışma bu eksikliği doldurmak için yapılmıştır. Araştırma kapsamında belirlenen yapay zekaya ait Instagram hesabı örnekleme alınmıștır. Bu Instagram hesabının yaptığı paylaşımların altında yer alan kullanıcı yorumları niteliksel (tematik) ve niceliksel içerik analizine tabi tutulmuştur. Elde edilen sonuçlar alanyazın doğrultusunda tanımlanarak yorumlanmıştır.

\section{Yapay Zeka Kavramı}

Günümüzde yapay zeka sistemleri; robot teknolojileri, dil işlemcileri, veri madenciliği, bilişim sistemleri, ders sistemleri, programlama, sezgisel süreçler, makine görüşü ve öğrenmesi gibi çeşitli araştırma alanlarında kullanılmaktadır (Topal, 2017, s. 1352). Pek çok farklı alanın konusu olduğu için her disiplinde farklı bir yönüyle ele alınan yapay zeka kavramının üzerinde uzlaşılmış ortak bir tanımı bulunmamaktadır (Kuşçu, 2015, s. 47). Genel hatlarıyla yapay zeka, herhangi bir canlı organizma barındırmaksızın yapay bir şekilde oluşturulmuş makinelere, algoritmalar yoluyla insana özgü hareketleri ve davranışları sergileme kabiliyeti kazandırmaya çalışan bir bilim dalı olarak açıklanabilir (Keleş, Keleş, \& Akçetin, 2017, s. 113; Mijwil, 2015, s. 3). Yapay zeka kavramı sekiz farklı tanım çerçevesinde, iki temel boyutta ve dört farklı kategoride sınıflandırılmaktadır. İlk boyutta bir bilgisayar yazılımının insan gibi düşünebilmesi ve insan gibi davranabilmesinden söz edilmektedir. Turing Testi ile açıklanan ilgili boyutta bahsedilen yapay zeka alanındaki çalışmaların amacı, insanı taklit edebilmek ve bir gün insan gibi olmaktır. İkinci boyutta ise bir bilgisayar yazılımının düșüncelerinde ve davranışlarında rasyonel (akılcı) bir şekilde hareket etmesi gerektiğinden bahsedilmektedir. İkinci boyut içerisinde tanımı yapılan yapay zeka çalıșmaları, insancıl tüm duygulardan bağımsız olarak rasyonel bir şekilde doğru olanı yaparak ideal zekaya ulaşmayı amaçlamaktadır (Russell \& Norvig, 2003).

Sembolik çıkarımsama ve yapay öğrenme, yapay zekayı oluşturan önemli bileșenler arasında yer almaktadır. İlgili bileșenler yapay zekaya sahip makinelerin ya da programların, insanlar gibi neden-sonuç ilişkisi kurmasını, veri üzerinde genellemeler yapabilmesini ve daha önce hiç karşılaşılmamış sorunlara çözümler üretebilmesini sağlamaktadır (Köroğlu, 2017, s. 2). Uzman sistemler, bulanık mantık, yapay sinir ağları, makine öğrenmesi ve genetik algoritmalar ise başlıca yapay zeka teknolojilerini oluşturmaktadır. Sözü edilen yapay zeka teknolojilerine ek olarak doğadan yola çıkılarak oluşturulan karınca kolonisi, parçacık sürü optimizasyonu ve yapay arı kolonisi gibi algoritmalar da modellenerek yapay zeka teknolojilerinde kullanılan tekniklerdendir (Atalay \& Çelik, 2017, s. 158; Saplıoğlu \& Uzundurukan, 2019, s. 251). 
Alanyazın incelendiğinde yapay zeka çalışmalarının, zayıf yapay zeka ve güçlü yapay zeka olmak üzere iki farklı ekole ayrıldığı görülmektedir (O’Regan, 2012; Öztürk \& Şahin, 2018; Topal, 2017). Zayıf yapay zeka, makinelerin programlanarak zeki davranışlar göstermesidir. $\mathrm{Bu}$ durumda makineler aslında anlama ve anlamlandırma süreçlerini yerine getirmemektedir. Programlanmalarının sınırları içerisinde, onlara bağlı olarak düşünceyi taklit etmekte ve bilme eylemini gerçekleştirmektedirler (O'Regan, 2012, s. 237-238). Dar zeka olarak da adlandırılan zayıf yapay zekalar, sadece tek bir konuda uzmanlaşabilmektedir. Satrançta dünya şampiyonunu yenen yapay zeka gibi günümüzde ana akım medyada karşılaştığımız tüm yapay zeka uygulamaları da zayıf yapay zeka ekolüne örnek olarak verilebilir (Özel, 2016). Güçlü yapay zeka ekolünde ise uygun bir şekilde programlanmış bir bilgisayar, anlama kapasitesine sahip bir zihin görevi görmektedir (Topal, 2017, s. 1354). Başka bir ifadeyle, güçlü yapay zekalar veriler üzerinde karmaşık algoritmik hesaplar yapan, verileri yorumlayabilen ve verilen hedeflere programlanmış yollar dışında alternatif yollar üreterek sonuca ulaşabilen oluşumlar olarak ifade edilebilir. Güçlü yapay zeka, zayıf yapay zekaya göre insana daha yakın özellikler taşımasından ve daha akıllı olmasından dolayı pek çok tartışmanın ortaya çıkmasına neden olmuştur. Bir grup yazar makinelerin doğru-yanlış, iyi-kötü ayrımını yapamayacağını ve insana özgü duygulara sahip olamayacağını savunurken, diğer bir grup ise makinelerin de insan beyni gibi hareket edebileceklerini ileri sürmektedir (Öztürk \& Şahin, 2018, s. 25).

\section{Yapay Zeka Kavramının Tarihçesi}

İnsanoğlunun otomatik makineler yapma veya cansız nesnelere hayat vererek kendisi gibi zeki varlıklar yaratma isteğinin ve denemelerinin aslında tarih öncesi dönemlere dayandığı bilinmektedir. Ancak yapay zeka alanın temelleri resmi olarak 1950'li yıllarda atılmıştır (Kuşçu, 2015; Lewis \& Writer, 2014). İngiliz matematikçi, yapay zekanın kurucusu ve bilgisayar biliminin en önemli isimlerinden biri olarak kabul edilen Alan Turing, İkinci Dünya Savaşından sonra 1950 yılında yayımladığı "Computing Machinery and Intelligence" adlı makalesinde "Makineler Düşünebilir mi?" sorusunu sorarak makinelerin zekasını tartışmaya açmıştır. İlgili soru doğrultusunda, makinelerin akıllı olup olamadığını belirlemek adına "taklit oyunu" olarak da bilinen bugünkü bilgisayarların alt yapısını oluşturan Turing Testi'ni geliştirmiştir. Testte, soruları yöneltmek için bir sorgulayıcı, soruları cevaplamaları için ise bir insan ve bir makine farklı kabinlerde olacak şekilde konumlandırılmaktadır (Aslan, 2014, s. 16). Sorgulayıcı aldığı cevaplardan yola çıkarak karşısındakinin makine olup olmadığını tespit etmeye çalışmaktadır. Test sonucunda makinenin zeki kabul edilebilmesi için ise sorgulayıcının, soruları yönelttiği makineyi insandan ayıramaması gerekmektedir (Russell \& Norvig, 2003, s. 2). Günümüzde, başta Amerika Birleşik Devletleri (ABD) olmak üzere pek çok ülkede yapay zeka alanında yapılan çalışmaların başarısı Turing Testi aracılığıyla değerlendirilmektedir (Küçükvardar, 2015, s. 44).

Terim olarak "Yapay Zeka" ise ilk kez 1956 yılında ABD'de düzenlenen Darthmouth Konferansı'nda John McCarthy tarafından önerilmiştir. Aynı yıl Allen Newell, J.C. Shaw ve Herbert Simon tarafında ilk yapay zeka programı olan "Logic Theorist" geliștirilmiștir (Küçükvardar, 2015, s. 43). 1957 yllına gelindiğinde ise McCarthy tarafından yapay zeka için geliştirilen oldukça güçlü, işlevsel ve hala kullanılmakta olan programlama dili LISP bilim dünyasına tanıtılmıştır (Mijwil, 2015, s. 2). 1950’de “Makineler düşünebilir mi?" sorusuyla başlayan yapay zeka çalışmalarının gün geçtikçe geliştiği, genişlediği ve evrildiği görülmektedir. Bu süreç içerisinde yapay zeka teknolojilerinin duraksama yaşadığı iki 
dönem bulunmaktadır. Bu dönemlerden ilki 1974-80 yılları arasında, ikincisi ise 198793 arasında yașanmış olup, "Yapay Zeka Kışı (AI Winter)" olarak adlandırılmaktadırlar. İlk yapay zeka kışı olarak bilinen dönemde yapay zeka geliştirme süreçleri pek çok eleștiriye maruz kalmış, gerçek dıșı beklentiler yüzünden hayal kırıklıkları yaşanmış ve sonuç olarak da yapay zekaya ilgi azalmış ve devletler bu alana olan desteklerini çekmişlerdir. Yapay zeka teknolojileri alanında ikinci kış deneyiminin yaşanmasının nedeni ise, kişisel bilgisayarların marketlerde kendilerine yer bulamamasından dolayı tekrar bu alana yapılan devlet desteğinin kesilmesi olarak açıklanmaktadır (Durakcan, 2015). 1997'de IBM tarafından geliştirilen Deep Blue isimli bilgisayarın dünyaca ünlü satranç oyuncusu Kasparov'u yenmesiyle yapay zeka alanındaki araştırmalar tekrar canlanmıştır. 1980’lerden itibaren yapay zeka teknolojilerinin pratik uygulamalarda, büyük projelerde ve gündelik yaşam problemleri üzerinde kullanılmaya başlandığını söylenebilir. Üstelik gelinen noktada, yapay zeka teknolojisinin daha ekonomik yazılım ve araçlarla birleştirilerek geniş bir kullanıcı kitlesine ulaştırılabildiği görülmektedir (Mijwil, 2015). Bilgi çağı olarak da adlandırılan 2000'li yıllara gelindiğindeyse hayatın her alanına sızan yapay zeka teknolojilerinin bilgiyi kullanan ve bilgi teknolojisini yönlendiren temel araçlar haline geldikleri söylenebilir (Keleş, Keleş, \& Akçetin, 2017, s. 114). 2011'de bilgisayar Watson'ın soru cevap yarışmasında, programın şampiyonlarını yenmesi ve 2017'de AlphaGo'nun, Go'da dünya şampiyonu Ke Jie'yi yenmesi yapay zeka teknolojisinin geldiği aşamayı gözler önüne seren örneklerdir. 2019 yllında ise insan zekası gerektiren işler, yapay zekaya sahip bilgisayar programlarıyla yapılabilmekte ve çeşitli sorunlar bu sistemler sayesinde daha hızlı bir şekilde çözülebilmektedir.

\section{Yapay Zekanın Geliştirilmesindeki Amaçlar ve Uygulamaları}

Gündelik hayat içerisinde insanlar, yaşamlarını kolaylaştıran faktörlere yönelme eğiliminde hareket etmektedir. Bu noktada yapay zeka uygulamaları, yaşanılan dijital çağda insanların vazgeçilmez tercihleri olmuştur. Alanyazın değerlendirildiğinde, yapay zekanın en önemli amaçlarından birinin insan hayatına entegre olarak hayat standartlarını yükseltmesi ve büyük kolaylıklar sağlaması olduğu görülmektedir (Barth \& Arnold, 1999; Jacob, Moore, \& Whinston, 1988; Kuşçu, 2015; Onay \& Övür, 2018; Power, 2003; Yıldız \& Yıldırım, 2018). Yapay zeka sayesinde insan hayatında yaratılan kolaylıklar bilime, eğitime, endüstriye kısacası hayatın her alanına dokunmaktadır. Söz konusu yaşanılan dijital çağda olunca yapay zekanın hız kesmeden ilerlemesi kaçınılmaz bir sonuç olarak karşımıza çıkmaktadır. Yapay zekanın bu kadar hızlı ilerlemesinde, dolaşımda olan verinin giderek artmasının rolü büyüktür. Aynı zamanda elde edilen verilerin işlenmesi gerektiği de önemli bir etkendir. Çünkü dünyadaki veri giderek artarken, bu verileri işleme kapasitesi de doğru orantılı olarak artmaktadır (Başer, 2018). Yapay zeka hayatın her alanında var olmakla birlikte, özellikle mühendislik alanında yapılan çalışmalarla adından sıkça söz ettirmektedir (Bozüyük, Yağcl, Gökçe, \& Akar, 2005, s. 7). Bu alanda yapılan çalışmaların amacı; insanlar üzerindeki iş yükünü hafifletecek, yardımcı zeki programlar/robotlar geliştirerek fayda sağlamaktır (Kocabaş, 2015, s. 2; Onay \& Övür, 2018, s. 134). Geliştiren programların/robotların karar verme, uzmanlık gerektiren alanlarda ve bilginin kullanılmasında işlevsellik sağladığı söylenebilir.

Yapay zeka çalışmaları kullanım amaçlarına göre sınıflandırılmaktadır. $\mathrm{Bu}$ amaçlar; davranışa dayalı, kurala dayalı ve bilgiye dayalı olarak sıralanmaktadır (Barth \& Arnold, 1999, s. 134). Davranışa dayalı yapay zeka çalışmalarının amacı, çeşitli sektörlerde karar verme süreçlerine destek olmaktır. Bu desteği de, geliştirilen bilgisayar yazılımları sayesinde sağlamaktadır (Jacob, Moore, \& Whinston, 1988, s. 26). Bir işletmenin 
müşterileriyle yaşadığı sorunlarda karar vermeyi kolaylaştırıcı simülasyonların geliştirilmesi (Power, 2003, s. 1) davranışa dayalı yapay zeka çalıșmasına örnek olarak verilebilir.

Yapay zekanın kullanım amaçlarında bir diğeri de, kurallara dayalı bir amaç gütmesidir. Kurallar denince akla uzman sistemler gelmektedir (Barth \& Arnold, 1999, s. 134). Uzman sistemler, yapay zeka çeşitlerinden birisidir (Önder \& Saygll, 2018, s. 636). Özellikle tıp ve askeri alanda örneklerini görmek mümkündür (Hurlay \& Wallace, 1986; Shortliffe, 1977). Yapay zeka geliştirme çabalarının diğer bir amacı, eğitim kalitesini artırmak, yaşanan teknolojik gelişmelere entegre olabilmek içindir. Bu amaç, bilgiye dayalı amaç sınıflandırması içerisine girmektedir (Barth \& Arnold, 1999). Kullanılan yapay zeka ile hem eğitimcilerin hem de öğrencilerin çağın gerisinde kalmadan, doğayı ve hayatı sorgulama kabiliyetlerinin gelişeceği öngörülebilir. Böylelikle bilimsel araştırmaların niceliksel ve niteliksel anlamda değer göreceğini de söylemek mümkündür. Alanyazında insanların kendi zekaları doğrultusunda, geliştirdikleri yapay zeka ile kendi zekalarının sınırlarını çözmek istedikleri üzerinde durulmaktadır (Kuşçu, 2015, s. 47). Dolayısıyla bilimsel bir amaçtan söz edilmektedir. İnsan zekasının birçok niteliği olduğu belirtilmektedir. $\mathrm{Bu}$ nitelikler; akıl yürütmeden, algllamaya, hüküm vermeye kadar değişmektedir. Zekanın bu niteliklerini geliştirilen programlar ve robotlar üzerinde görme amacını taşıyan insan, yapay zeka üzerinde çalıșmalarını hızlandırmaktadır (Yıldız \& Yıldırım, 2018, s. 27). Dolayısıyla yapay zeka çalışmalarının bilimsel amacının da göz ardı edilmemesi gerekmektedir. Temel prensibi insan hayatının kolaylığı üzerine konumlanan yapay zeka çalışmaları her ne kadar pozitif bir çerçeve çizmiş olsa da, negatif tarafını da sorgulamak gerekmektedir.

Yapay zekanın yaygınlaşarak kullanılmasında, zaman içerisinde tek tip bir insan topluluğunun oluşabileceğine dikkat çekilmektedir (Onay \& Övür, 2018, s. 134). Bu tek tip insan topluluğunda, yapay zeka kullanımının bir rekabete dönüşmesi (Öztemel, 2012, s. 13 ) ise, tüketim toplumunun evrimleşme sürecinin önemli bir parçası olarak görülebilir. Çeşitli amaçlar doğrultusunda geliştirilen yapay zekayı, yer aldığı uygulamalar içinde değerlendirmek yararlı olacaktır.

Yapay zeka tekniklerinden biri olan bulanık mantık tekniği doğrultusunda; beyaz eşyaların, akıllı ev sistemlerinin, elektronik araç gereçlerin geliştirildiği görülmektedir (Bozüyük, Yağcı, Gökçe, \& Akar, 2005, s. 37). Bu teknik içinde trafik sisteminin gelişimi de söz konusudur. Yapay zeka sayesinde yoğun trafik akışlarında geliştirilen sistem, önceden enformasyon elde ederek trafik ışıklarının yanma sürelerini ayarlamaktadır (Vashisht, 2017). Örneğin Türkiye'de de, trafikteki ihlalleri kayıt altına almak için akıllı sistemler olarak bilinen dronlar kullanılmaktadır (Önder \& Saygılı, 2018, s. 650). Yapay zeka teknikleri arasında uzman sistemleri ve yapay sinir ağları da yer almaktadır. Bu uzman sistemler ve yapay sinir ağlarının; tıp alanında, haberleşme alanında, askeri alanda ve robotik uygulamalarda kullanıldığı görülmektedir (Hurlay \& Wallace, 1986). Uzman sistemler yapay zekanın kurala dayalı kullanım amacını yansıtmaktadır (Barth \& Arnold, 1999). Çin'de geliștirilen robotik uygulamalar ile yapay zekaya sahip doktorların doğru hastalık tespitleri yaptıkları görülmüştür (Çin'de bir robot, 2017). Genetik algoritmalar yapay zeka tekniği doğrultusunda ise, bilgisayar oyunlarının geliştirildiği görülmektedir. Örnek olarak Sims adlı bilgisayar oyunu verilebilir. Bu oyunda, gerçek yaşamın aynısının dijital ortamda yaratıldığı görülmektedir (Pirim, 2006, s. 91). Öte yandan yapay zeka uygulamalarının dijital pazarlama alanında da, çeşitli sektörlerde kullanıldığı dikkat 
çekmektedir. Pazarlama alanındaki birçok şirketin, büyük veriyi toplamak ve sınıflandırıp analiz ederek hedef kitlesini daha görünür hale getirmek için uğraştığı söylenebilir.

Örneğin Pfizer şirketi yapay zekayı pazarlama alanında sıkça kullanmaktadır. Şirketin Avusturya ayağının, Complexica'nın What-If Simülatörü'nü kullanarak, iç ve dış değerleri göz önüne alarak gerçek pazarlama senaryolarını analiz edebildiği görülmektedir. Veri analiz görevini üstlenen bu simülatör sayesinde iş gücü ve para kaybına sebep olabilecek faktörlerde ortaya çıkartılabilmektedir (Cameron, 2017). Dijital pazarlamada yapay zeka uygulamalarına bir diğer örnek ise, The Economist dergisinin programatik reklamları kullanması verilebilir. Dergi kullandığı yazılımlar ile dijital medyadaki kullanıcılarının okuma tercihlerini elde ederek veri analizlerini gerçekleştirmektedir. Web sitelerinde kullanılan çerez uygulamalar ile hedef kitlesinin profilini analiz edebilmektedir (Sor'un, 2019). Amazon ve Netflix web sitelerinde de, yapay zeka uygulamalarının yer aldığ görülmektedir. Şöyle ki, girilen web sitelerinde kullanıcıların kayıt olmaları istenmektedir. Kayıt sırasında kullanıcı kendini tanımlayıcı bazı nitelikleri (ev adresi, sevdiği müzikler veya filmler, indirilen uygular vb.) belirtmektedir. Bu tarz sitelerde, DSSTNE adlı yapay zeka uygulamasını kullanarak, kullanıcıların niteliklerine göre satın alabilecekleri ürün önerilerinde bulunulmaktadır (Soylu, 2018). Örneğin, daha önceden akıllı bir telefon satın aldıysanız, girdiğiniz web sitesinde telefonun aksesuarlarını tavsiye eden reklamlarla karşılaşılabilirsiniz. Dijital pazarlama alanında yapılan bu uygulamaların ortak özelliğinin aslında kurumların hedef kitlesine yönelik kişiselleştirilmiş uygulamaları olduğu görülmektedir.

Verilen örnekler yapay zeka uygulamaları hakkında yüzeysel bir bilgi sunmaktadır. Günümüzde yapay zeka uygulamalarının, hız kesmeden daha çok geliştirildiğini Google'ın DeepMind adlı yapay zeka şirketinin yapmış olduğu çalışmalarda görmekteyiz. Yapılan çalışmalarda yapay zekaya artık "hayal gücü” yetisi de eklenmiștir. Bu sayede yapay zekalar yaptıkları davranışlar üzerine düşünüp herhangi bir yargılamada bulunabilmektedir (Jain, 2017). Geliştirilen en gerçekçi yapay zeka örneğinin Sophia adındaki robotta olduğunu görmekteyiz. Suudi Arabistan vatandaşı olan Sophia, konuşulanları anlayan ve üzerine cevaplar veren bir yapay zeka örneğidir (Kayıkçı \& Bozkurt, 2018). Eğitim alanında adından sıkça söz ettiren yapay zeka örneği ise Türk işaret dili robotudur. Çocuklar için geliştirilen robot, taklit etme yoluyla oyun oynama üzerinden işaret dili eğitimi vermeyi misyon edinmiştir (Köse, 2017). Görülüyor ki, yapay zeka uygulamaları insanoğlunun evrimsel sürecinin bir parçasıdır. İnsanlar kedilerini keşfetmeye devam ettikçe, ihtiyaçları arttıkça yapay zeka uygulamalarının gelişeceği ve giderek artacağı söylenebilir. Yeni olanın arzulandığı, ilgi duyulduğu dijital çağda var olan insanların, yapay zeka uygulamalarına karşı yönelimlerinin de artacağı ön görülebilir.

\section{Yeniliklerin Yayılımı Kuramı ve Yapay Zeka Ürünü Sanal Etkileyenler}

Everett M. Rogers, ve G. Tarde'nin yaklaşımı olan yeniliklerin yayılımı kuramı, ortaya çıkan bir yeniliğin toplumsal sistem içinde belirli bir zaman sürecindeki uyum aşamalarına işaret etmektedir (Agarwal, Ahuja, Carter, \& Gans, 1998). Bu yaklaşım, ortaya çıkan yeniliğin toplum tarafından kabul ya da reddedilmesi sürecini ele almaktadır (Berger, 2005). Yeniliklerin yayılımında dört unsurdan bahsedilmektedir. Bunlar; yenilik, iletişim kanalları, zaman ve toplumsal sistemdir (Rogers, 2003). Günümüzde ise, iletişim teknolojilerinde yaşanan gelişmeler ışığında toplumsal sistemin daha fazla yeniliğe maruz kaldığı söylenebilir. Özellikle sosyal medyanın insanın gündelik hayatının merkezinde yer alması ve bu yeniliklerden haberdar etmesi yeniliklerin yayılım sürecini hızlandırdı̆̆ı görülmektedir. 
Araştırma kapsamında yenilik olarak yapay zekanın ortaya çıkışı ele alınmaktadır. Yapay zeka uygulamalarının hayatın her alanında yer alması insanlar tarafından kabul görmesine ya da red edilmesine neden olmaktadır. Yapay zekanın yayılma sürecinde sosyal medyanın rolünün büyük olduğu görülmektedir. Instagram uygulaması ise, yapay zekanın toplumsal sistem içinde yayılmasındaki iletişim kanalıdır. Instagram'da yer alan yapay zekalar sanal etkileyen olarak adlandırılmaktadır. Dijital etkileyenler ile pek çok ortak noktası bulunan sanal etkileyenlerin en büyük özelliği gerçekte var olmamalarıdır. Sanal etkileyenler, genellikle büyük bir ekip tarafından ve 3D animasyon uygulamaları aracılığıyla yaratılan dijital karakterlerdir (Darner \& Arvidsson, 2019, s. 6). Bilgisayar tarafından olușturulan imajlar (Computer Generated Images- CGI) olarak da adlandırılan yapay zeka ürünü sanal fenomenler ilk defa 2016 yılında, özellikle yeni teknolojiyle büyüyen ve boş zamanlarının çoğunu Instagram üzerinde geçiren $\mathrm{Z}$ kuşağını etkileyebilmek amacıyla yaratılmıştır (Yalçın, 2019). Günümüzde gençler için oldukça çekici hale gelen sanal fenomenler, tıpkı dijital etkileyenler gibi gün içerisindeki farklı anlarını takipçileriyle paylaşmakta, hatta markalarla çeşitli kampanyalar düzenleyerek iş birliklerinde bulunmakta ve reklamlarda markaları temsil etmektedirler (Virtual influencers, 2019). HypeAuditor'un son verilerine göre sanal etkileyenler, dijital etkileyenlere kıyasla takipçileriyle üç kat daha fazla etkileşime geçmekte ve içerikleri sosyal medya kullanıcıları tarafından daha fazla ilgi görmektedir Ayrıca ilgili veriler, yapay zeka ürünü sanal etkileyenlerin üç ay gibi kısa bir süre içerisinde \%70'lik pozitif bir büyümeye sahip olduğunu göstermektedir (Baklanov, 2019).

Instagram'da yaratılan sanal etkileyicilerin ilk örneği ve sanal karakterlerin en popüleri olan 19 yaşında yarı İspanyol yarı Brezilyalı olarak tasarlanan Lil Miquela, Los Angeles şehrinde bulunan Brud şirketinin yarattığı üç yapay zekadan biridir. Piyasaya ilk çıkışlarından itibaren kendilerini robotik ve yapay zeka alanlarında uzmanlaşmış bir şirket olarak tanıtan Brud, son zamanlarda kendilerini ve yaptıkları işi "dijital karakterler odaklı hikaye dünyaları yaratan bir transmedia stüdyosu" olarak tanımlamaktadır (Bendoni \& Danielian, 2019). İlk bakışta sıradan genç bir kadına benzeyen Miquela ve diğer sanal etkileyenler, Instagram sayfalarında tıpkı marka öncüleri ya da dijital etkileyenler gibi moda marklarını tanıtmakta, güzellik ürünlerini tavsiye etmekte, takipçilerinin yorumlarına cevap vererek hayranlarıyla sıklıkla iletişime geçmekte ve ünlü markalarla iş birliklerinde bulunmaktadırlar. Örneğin Prada, Ugg, Moncler Genius, Diesel, Calvin C. ve Samsung sanal fenomen Miquela'nın reklam işbirliği yaptığı markalar arasındadır (Bingöl, 2018; Büyükdumlu, 2019). Kendilerini Instagram sayfalarında bir birey olarak konumlandıran sanal etkileyenlerin çoğunun ilk başta anonim kalması ve insan olmadıklarının, yapay zeka ürünü ya da CGI olduklarının açık bir şekilde belirtilmemesinin karakterlerin etrafında bir gizem ve hayranlık yarattığı söylenebilir.

Sanal etkileyenlerin başta anonim olmalarının sağladığı gizem sayesinde takipçi kazanmaya başladıklarına dikkat çekilmektedir (Darner \& Arvidsson, 2019). Sanal etkileyenlerin gerçek olmadıklarının bilinmesi sosyal medya kullanıcılarıyla aralarında duygusal bağ kurmalarını zorlaştırmaktadır. Tüketiciler yapay zekaya tam olarak güvenememekte ve dolayısıyla da sanal fenomenler, takipçilerini satın alma davranışına yönlendirememektedir (Walter, 2019). Ancak pek çok sanal etkileyenin insan olmadıklarının açıklanmasından sonra da takipçi sayılarının artmaya devam etmesi, yapay zekanın sosyal medya ortamındaki kabulüne yönelik önemli bir gelişme olarak değerlendirilebilir. Bu duruma en iyi örnek olarak Miquela'nın ve Shudu'nun Instagram sayfaları gösterilebilir. 
Sanal influencer ajanslarının daha bebeklik döneminde olduğu ifade edilmekte ve bu olay Brud şirketinin dramayı kullanarak düzenlediği umut verici bir pazarlama faaliyeti olarak tanımlanmaktadır. Yaratılan bu distopik drama sayesinde ilgili sanal karakterler medyanın ve yatırımcıların ilgisini çekmeyi başarmıştır (Sokolov, 2019). Miquela'nın insan değil, bir yapay zeka olmasının anlaşılmasıyla beraber Instagram takipçilerinin ve etkileşimlerinin artması ise oldukça dikkat çekici bir durumdur. Ayrıca Highsnobiety ve Vmagazine gibi dergilerde de yer bulmayı başaran sanal fenomenin, Kanye West ve Rihanna gibi yıldızların bulunduğu Time'ın "Most Influential People on the Internet" listesinde ilk 25 arasında gösterilmesi Instagramdaki etki boyutunun büyüklügünü ve önemini gözler önüne sermektedir (Time, 2018). Ayrıca ilgili sanal etkileyen bu zamana kadar Fenty ve Balmain gibi pek çok markayla da iş birliklerinde bulunmuştur (Bingöl, 2018). Genellikle markalar ya da medya ajansları tarafından kontrol edilen sanal etkileyenlerin takipçi ve Instagram performans istatistik rakamlarına bakıldığında sosyal medya kullanıcılarının ilgisini çektiği ve dolayısıyla da Influencer pazarlaması için oldukça önem teşkil ettiği ve gelecekte de önemini koruyacağı söylenebilir. Tüketiciler hakkında İngiltere'de yapılan bir araştırma, 18-34 yaş arasındaki bireylerin sosyal medya ortamında takip ettikleri kişilerin gerçek olmadığını bildikleri halde takip etmeye devam ettiklerini göstermektedir. Ayrıca ilgili araştırmada, İngiltere'deki tüm tüketicilerin \%54'ünün, teknolojiye ilgili bireylerin ise \%64'ünün sanal karakterleri daha çekici bulduğunu ortaya koymaktadır. Bu durum, tüketicilerin Instagram'daki çoğu şeyin sahte olduğunu düşünmelerinden kaynaklanmaktadır. Buna göre, sosyal medya kullanıcıları güven duymadıkları paylaşımları takip ederek gizlice kandırılmaktansa, sahte olduğunu bildikleri bir karakteri takip etmeyi tercih etmektedirler (Harding, 2019).

Sözü edilen araştırmalardan hareketle, yapılan bu çalışma kapsamında yenilik olarak görülen yapay zeka ürünü sanal etkileyenin, bir birey konumunda hareket ettiği Instagram uygulamasında, takipçiler tarafından kabulüne yönelik bir inceleme yapılmak istenmiştir. Alanyazında konu kapsamında böyle bir incelemenin olmaması, söz konusu bu çalışmanın önemini ortaya çıkarmaktadır.

\section{Araştırmanın Amacı ve Yöntemi}

Günümüzde teknolojinin hızla gelişmesi birçok yeniliğin ortaya çıkmasına neden olmaktadır. İnsanların bu yenilikleri sorgulamadan benimsemesi ise oldukça dikkat çekmektedir. Bu noktada Instagram uygulaması ise önemli bir rol teşkil etmektedir. İnsanların, markaların ve kurumların kişiliklerini yansıttıkları bir mecra haline gelen Instagram'ın, yapay zekanın da kendisini görünür kıldığı çevrimiçi bir ortam olduğu görülmektedir. Bu doğrultuda çalışmanın amacı; Instagram'da kendini birey olarak konumlandıran, kurgusal bir karakter olan yapay zeka ürünü sanal etkileyenin, kullanıcılar tarafından nasıl algılandıklarını ortaya çıkarmaktır. Araştırmanın amacı kapsamında araştırma soruları şu şekilde belirlenmiştir:

Araştırma Sorusu 1: Instagram kullanıcıları yapay zeka ürünü sanal etkileyenin paylaşımlarını nasıl algılamaktadır?

Araştırma Sorusu 2: Yapay zeka ürünü sanal etkileyeni takip eden Instagram kullanıcılarının yaptıkları yorumların yönü nasıldır?

Çalışmada nitel araştırma geleneğinden yararlanılmıştır. Nitel araştırmalar; bireyler arasındaki ilişkileri, çeşitli faaliyetlerin, durumların ya da olguların niteliğinin derinlemesine incelendiği çalışmalardır (Fraenkel \& Wallen, 2006). Araştırmanın 
amacı ve merak edilen sorular çerçevesinde durum deseninin (case study) seçilmesi uygun görülmüştür. "Durum deseni, bir ya da daha fazla olayın, ortamın, programın, sosyal grubun ya da diğer birbirine bağlı sistemlerin derinlemesine incelenmesidir" (McMillan, 2000).

\section{Araştırmanın Örneklemi}

Çalışmanın amacı doğrultusunda, amaçlı örnekleme yöntemlerinden ölçüt örneklemesi tercih edilmiştir. Ölçüt örnekleme yönteminde örneklem seçiminde, araştırmacılar tarafından belirlenen ölçüt veya ölçütler kullanılabilir ya da daha önce farklı çalışmalarda kullanılmış bir ölçüt listesi uygulanabilir (Yıldırım \& Şimşek, 2013, s. 140). Araștırmacılar tarafından belirlenen ölçütler ise; çalışma dahilinde incelenecek Instagram hesabının kendisini bir birey olarak yansıtan yapay zekaya ait olması ve ilgili Instagram hesabında analiz etmeye yetecek düzeyde paylaşım ve kullanıcı yorumunun bulunmasıdır. "Lilmiquela" adlı Instagram hesabı belirlenen ölçütler ışığında araştırmanın örneklemi olarak belirlenmiștir. İlgili Instagram hesabı Lil Miquela olarak da bilinen, yapay zeka temelli bir sanal etkileyen (virtuel influencer) olan Miquela Sousa'ya aittir. 2016 yılında kurgusal bir karakter olarak geliştiren robot, sanal sanat projesi olarak adlandırılmaktadır. $\mathrm{Bu}$ yapay zekanın Instagram hesabının seçilmesinin diğer bir nedeni ise, 2018 yılında Time dergisi tarafından Instagramda en etkili kişiler arasında gösterilmesidir (Time, 2018).

\section{Veri Toplama Yöntemi ve Analizi}

Araștırma örnekleminde belirtilen Miquela Sousa'nın Instagram hesabında yaptığ paylaşımların altındaki kullanıcı yorumları niteliksel (tematik) içerik analizi ve betimsel içerik analizi yöntemiyle analiz edilmiştir. Niteliksel (tematik) içerik analizi araştırmacılar tarafından bilgisayar programı kullanılmadan manuel olarak ayrı ayrı yapılmıştır. Ardından elde edilen kategoriler ve temalar karşılaştırılarak fikir birliğine varılmıştır. Çalışma kapsamında belirlenen Instagram hesabında 2019 yılı içerisinde 4-10 Kasım ve 18-24 Kasım tarihleri arasında yapılan paylaşımların altındaki kullanıcı yorumları incelenmiştir. Belirtilen tarihler içerisinde ilgili Instagram sayfasından 13 post yayınlanmıştır. Her paylaşımdan 50 yorum araştırmaya dahil edilerek toplam 650 yoruma ulaşılmıştır. Yapay zekayı takip eden Instagram kullanıcılarının yaptıkları yorumların yönünü ortaya çıkartabilmek için ise, nitel veriye dayalı niceliksel içerik analizi yapılmıştır. Niceliksel içerik analizinde SPSS programı kullanılmıştır. Yapılan yorumlarda aranan değişkenler var (1) ve yok (0) şeklinde kodlanmıștır. Paylaşımlar P1, P2, P3... şeklinde kodlanmıștır ve paylașım tarihleri de yanında verilmiștir.

\section{Bulgular}

Araştırma Sorusu 1: Instagram kullanıcıları yapay zeka ürünü sanal etkileyenin paylaşımlarını nasıl algılamaktadır? 
Tablo 1. Elde Edilen Kategoriler ve Temalar

\begin{tabular}{|c|c|c|c|c|}
\hline $\begin{array}{l}\text { Tema 1: Pozitif } \\
\text { Yaklaşım - Kabullenme }\end{array}$ & $\begin{array}{l}\text { Tema 2: Negatif } \\
\text { Yaklaşım }\end{array}$ & $\begin{array}{l}\text { Tema 3: Duygusal } \\
\text { Yaklaşım }\end{array}$ & $\begin{array}{l}\text { Tema 4: Gerçekliğini } \\
\text { Sorgulama }\end{array}$ & $\begin{array}{l}\text { Tema 5: Satın } \\
\text { Almaya Yönlendirme }\end{array}$ \\
\hline Kategoriler & Kategoriler & Kategoriler & Kategoriler & Kategoriler \\
\hline $\begin{array}{l}\text { <Olumlu Mesajlar } \\
\text { < Heyecan Duyma } \\
\text { < Paylaşım } \\
\text { Yapmasını İsteme } \\
\text { < Merak Etme } \\
\text { < Robot olduğuyla } \\
\text { ilgili diğer } \\
\text { Takipçilere bilgi verme } \\
\text { <Yakınlık Bildiren } \\
\text { İsim Verme } \\
\text { <Dış Görünüşünü } \\
\text { Beğenme } \\
\text { <Onaylama } \\
\text { <Dijital İşçiliğini } \\
\text { Beğenme } \\
\text { < Yaptığı İşi } \\
\text { Benimseme } \\
\text { < Robot Olarak } \\
\text { Benimseme } \\
<\text { İnsan Olarak } \\
\text { Benimseme }\end{array}$ & $\begin{array}{l}\text { <Robotu } \\
\text { Onaylamama } \\
\text { <Robot } \\
\text { Düşmanlığı } \\
\text { < Korkma-Ürkme } \\
\text { <Ürpetici Bulma } \\
\text { <Insan gibi } \\
\text { davranmasından } \\
\text { rahatsızlık duyma } \\
\text { <Sevmeme- } \\
\text { olumsuz yorum }\end{array}$ & $\begin{array}{l}\text { < Kendine } \\
\text { Örnek Alma } \\
\text { < Duygusal İlişki } \\
\text { < Arkadaş } \\
\text { Olma İsteği } \\
\text { <Tanışma İsteği } \\
\text { <Birlikte Çalışma } \\
\text { İsteği } \\
\text { <Sanal Etkileyenin } \\
\text { Onu Fark Etmesini } \\
\text { İsteme } \\
\text { <Diğer sosyal } \\
\text { ağlardan iletişim } \\
\text { kurma isteği }\end{array}$ & $\begin{array}{l}\text { <Takipçinin Kafasının } \\
\text { Karışması } \\
\text { <Robot Olduğuna } \\
\text { İnanmama } \\
\text { <Robot Taklidi Yapan } \\
\text { İnsan Sanma } \\
<\text { Şaşırma }\end{array}$ & $\begin{array}{l}\text { <Kıyafetlerini } \\
\text { Beğenme } \\
\text { <Elbisesini satın } \\
\text { alma isteği } \\
\text { <Marka Sorma } \\
\text { <Modayla } \\
\text { Özdeştirme }\end{array}$ \\
\hline
\end{tabular}

\section{Pozitif Yaklaşım-Kabullenme Temasına Yönelik Takipçi Görüşleri}

Tema 1'in işaret ettiği nokta, Instagram takipçisinin yapay zekanın Instagram hesabından duyduğu heyecan, merak doğrultusunda daha fazla paylaşım görme isteğinin olduğudur. Aynı zamanda takipçilerin diğer takipçilere Instagram hesabının bir robota ait olduğunu söyleyerek bir bilgi kaynağı misyonu üstlendiğini göstermektedir. Bunun yanında yapay zekanın yaptığı işin takdir edildiği ve robot/insan şeklinde benimsendiği de dikkat çekmektedir. Tüm bu göstergelerde yapay zekanın Instagram hesabına pozitif yaklaşıldığını vurgulamaktadır. Bu temayı destekleyen takipçilerin yorumları şöyledir:

Bro Miquela Instagram'da canlı yayınlanırsa yemin ederim aklım uçar. (18 Kasım 2019-P7)

Brezilya'dan sevgilerle öpücükler (18-Kasım 2019 P7)

her işi gerçekten çok iyi yaptın seviyorum (18-Kasım 2019 P7)

Yeni şarkını gerçekten çok seviyorum Miq Seni seviyorum (18-Kasım 2019 P7)

Güzel bir robot (19 Kasım 2019-P8)

Çok mükemmelsin seni seviyorum!!! (19 Kasım 2019-P8)

Bu dünyada gördüğüm en tatlı insanlardan birisin. (20 Kasım 2019-P10)

Seni çok seviyorum (19 Kasım 2019-P9)

Bana kimin şarkı söylediği sorulduğunda onlara yapay bir robot olduğunu söylüyorum. (19 Kasım 2019-P9)

Saçını çok seviyorum!! Daha sık böyle yapmalısın! (24 Kasım 2019-P13)

\section{Negatif Yaklaşım Temasına Yönelik Takipçi Görüşleri}

Tema 2 Negatif Yaklaşımlar, yapay zekadan rahatsız olan ve olumsuz yorumlarda bulunan bir kesimin de varlığına işaret etmektedir. Özellikle ilgili tema altında toplanan yorumlarda gerçeküstü bir robotun insan gibi davranmasından ve insanların da bu durumdan hoşnut olmasından duyulan rahatsızlık dikkat çekmektedir. Ayrıca fenomen robotun takipçileri tarafından insan olarak benimsenmesine tepki gösteren bu kişilerin, başkaları tarafından yapay zekanın yaptığı işlerin beğenilmesine, merak edilmesine ve takip edilmesine de tepkili oldukları görülmektedir. İlgili temanın robotu onaylamama, 
robot düşmanlığı, insan gibi davranmasından rahatsızlık duyma, sevmeme ve olumsuz yorum alt kategorilerinin işaret ettiği bazı yorumlar şu şekildedir:

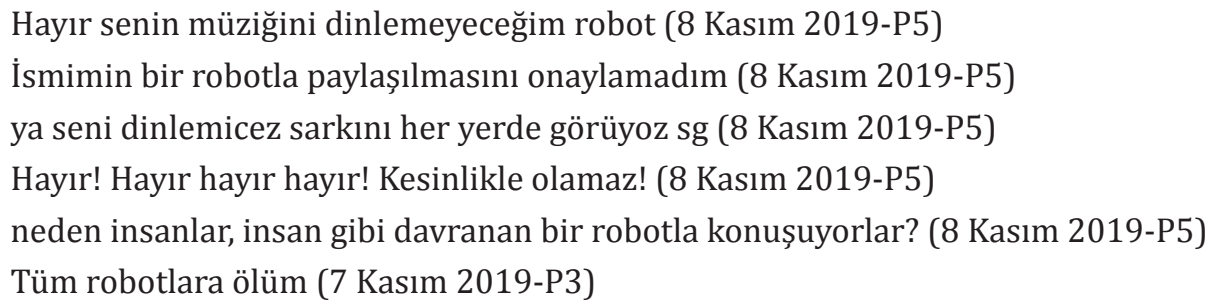

İlgili tema çerçevesi içerisine giren alt kategorilerin işaret ettiği diğer bir önemli nokta ise yapay zekanın oldukça gerçekçi bir şekilde kurgulanmasından ve insana olan yüksek benzerliğinden dolayı takipçiler tarafından oldukça ürpertici ve korkutucu bulunduğudur.

Bu hesaplar ürpertici yedik lol (4 Kasım 2019- P1)

(Başkasını etiketleme) evet o... işte bu yüzden garip (8 Kasım 2019-P5)

Beni inanılmaz derecede korkutuyorsun (10 Kasım 2019-P6)

\section{Duygusal Yaklaşım Temasına Yönelik Takipçi Görüşleri}

Tema 3 olan duygusal yaklaşım ise, Instagramda yapay zekanın yaptığı paylaşımların takipçiler tarafından örnek alındığına işaret etmektedir. Bunun yanında takipçilerin yapay zekayla yakın ilişki kurmak isteği, arkadaş olmak istediği ve yapay zekanın onu fark etmesini istediği görülmektedir. Bu temayı destekleyen takipçi yorumları aşağıdaki gibidir:

\footnotetext{
Benim için böyle bir ilham kaynağısın aşk ve HER ZAMAN (18 Kasım 2019-P7)

Biz arkadaş olabiliriz lütfen (19 Kasım 2019-P8)

Sen benim idolümsün (19 Kasım 2019-P9)

Sen benim kahramanımsın (20 Kasım 2019-P10)

Bana çok ilham veriyorsun (20 Kasım 2019-P10)

Seninle tanışmak istiyorum sen çok tatlısın (20 Kasım 2019-P10)

Awww! Sen benim favorimsin ve seni takip etmeyi sevdim!!! Ve şimdi bana çekirdek üzerinde çalışmam için ilham verdin (22 Kasım 2019-P11)
}

\section{Gerçekliğini Sorgulama Temasına Yönelik Takipçi Görüşleri}

Takipçinin kafasının karışması, robot olduğuna inanmama, robot taklidi yapan insan sanma, şaşırma alt kategorilerinden oluşan "Gerçekliğini Sorgulama" Tema 4'ü oluşturmaktadır. İlgili temada takipçilerin, yapay zekanın/robotun insana olan yüksek benzerliğinden ötürü yaşadıkları şaşkınlık ve kafa karışıklığına işaret etmektedir. Bu tema altında toplanan yorumlarda sıklıkla sanal fenomene robot mu insan mı olduğu konusunda soru yöneltildiği ve diğer takipçilerin de kafası karışmış bu kişilere bilgi verdiği görülmektedir.

Üç farklı arkadaşını etiketleyerek) oğlum bu gerçek mi lan (4 Kasım 2019-P1)

Şu an kafam inanılmaz derecede karıştı (4 Kasım 2019-P1)

O bir robot mu? (5 Kasım 2019-P2)

O nedir (4 Kasım 2019-P1)

Hindistan'dan (Hindistan bayrağı emojisi) merhaba @lilmiquela ben anushka sen bir insan misın ya da bir robot musun?? (7 Kasım 2019-P3)

bekle bu da nesi (5 Kasım 2019-P2)

Gerçekten kafam karıştı. Sen resmen robot musun çünkü aklımı kaçırıcam (8 Kasım 2019-P5) 
Sanal etkileyenin oldukça gerçekçi çiziminin ve kurgusunun takipçilerin kafasında insanla-robot ayrımını bulanıklaştırdığı söylenebilir. Ayrıca sanal etkileyenin bir yapay zeka/robot olduğunun açık bir şekilde belirtilmesine rağmen bir kesim hala robotun gerçek bir insan olduğuna, hatta bir insanın ilgi çekmek amacıyla Instagram filtrelerinden yararlanarak kendini bir dijital karakter gibi gösterdiğine inanmaktadır.

Sen bir robot değilsin filtre kullanıyorsun. (4 Kasım 2019-P1)

Sen bir robot musun yoksa maske giyen bir insan misin? (4 Kasım 2019-P1)

Bu Çok garip .... İnsan gibi görünmüyorsun, aynı zamanda insan gibi görünüyorsun. Kafam karıştı (5 Kasım 2019-P2)

Farklı birini etiketleyerek) sen ... Aslında bir robot olduğuna inanıyor musun? Bu bir karakter ve kendini ifade etme șekli. 0 bir sanatçı. (8 Kasım 2019-P5)

Sen robot olduğuna emin misin XD (5 Kasım 2019-P2)

Yapay zeka değil (8 Kasım 2019-P5)

Nasıl kendini robot gibi gösteriyorsun??? (8 Kasım 2019-P5)

\section{Satın Almaya Yönlendirme Temasına Yönelik Takipçi Görüşleri}

Tema 5 ise kıyafetlerini beğenme, elbisesini satın alma isteği, marka sorma ve modayla özdeştirme alt kategorilerinden oluşturmaktadır. Araştırma dahilinde incelenen yorumlarda sıklıkla sanal etkileyenin görünüşüne, saçına ve özellikle de kıyafetlerine iltifat edildiği dikkat çekmektedir. Dolayısıyla paylaşımlar aracılığıyla önemli bir etkileme söz konusudur. İlgili tema altındaki yorumlarda takipçilerin, yapılan paylaşımlarda sanal etkileyenin kıyafetlerinden ve kullandığı eșyalardan etkilendiği görülmektedir. $\mathrm{Bu}$ etkilenme sonucu takipçiler yapay zekanın kullandığı markaları merak etmekte ve paylaşımlarda markaların taglenmesini (etiketlenmesini) talep etmektedirler.

Elbiseyi etiketle güzel bayan elbise çok tatlı (10 Kasım 2019-P6)

Güzel kiyafetler(5 Kasım 2019-P2)

Botlarını seviyorum! (5Kasım 2019-P2)

Saçlarını seviyorum (7 Kasım 2019-P3)

Vanslar konuşuyor (7 Kasım 2019-P4)

Şifonyer, @uzumaki.gallery tarafından mı dekore edildi (10 Kasım 2019-P6)

Bu elbiseyi nereden aldığını bilmeliyim (18 Kasım 2019-P7)

Bu elbiseyi nereden alabilirim? Çok güzel! (20 Kasım 2019-P10)

Moda senin göbek adın (22 Kasım 2019-P11)

Araştırma Sorusu 2: Yapay zeka ürünü sanal etkileyeni takip eden Instagram kullanıcılarının yaptıkları yorumların yönü nasıldır?

Tablo 2. Instagram Takipçilerin Yaptıkları Yorumların Yönü

\begin{tabular}{|l|l|c|c|}
\hline \multicolumn{2}{|l|}{ Lil Miquela Instagram Hesabı } & Frekans (n) & Yüzde (\%) \\
\hline \multirow{3}{*}{ Takipçi Yorumunun Yönü } & Olumlu & 451 & 69,4 \\
\cline { 2 - 4 } & Olumsuz & 60 & 9,2 \\
\cline { 2 - 4 } & Nötr & 139 & 21,4 \\
\hline Toplam & 650 & 100,0 \\
\hline
\end{tabular}

Sonuç ve Değerlendirme

$\mathrm{Bu}$ çalışma Instagram'da kendini bir birey olarak yansıtan yapay zekanın, Instagram takipçileri tarafından kabulünü yeniliklerin yayılımı kuramı bağlamında ele almaktadır. Niceliksel ve niteliksel analizler ile yeniliklerin yayılımı bağlamında yapay zekanın insan 
olarak Instagram'da yer almasını takipçilerin bakış açıları doğrultusunda değerlendirerek konuya farklı bir bakış getirmektedir. Araştırmanın ilk sorusu için yapılan niteliksel (tematik) içerik analizi sonucunda; Tema 1, Tema 3 ve Tema 5 Instagram takipçisinin yapay zeka ürünü sanal etkileyeni kabullendiğini göstermektedir. Tema 4 takipçinin kabullenme sürecini etkileyen bir bulgu olarak ortaya çıkmaktadır. Tema 2 ise, yapay zekayı kabullenmeyen takipçilerin de olduğuna işaret etmektedir.

Araştırma ile ulaşılan Tema 1, pozitif yaklaşım-kabullenme içerisinde yer alan kategoriler; heyecan duyma, merak etme, onaylama, robot olarak benimseme, paylaşım yapmasını isteme vb. şeklindedir. Takipçilerin pozitif yaklaşımının altında duygusal faktörlerin yer aldığı söylenebilir. Elde edilen bulgularda, duygusal yaklaşım olarak belirlenen Tema 3 de sözü edilen durumu desteklemektedir. Bu temayı işaret eden alt kategorilerde, sosyal medya kullanıcılarının sanal etkileyeni örnek aldığı ve sanal fenomenle yakın bir ilişki kurma isteğinde oldukları görülmektedir. Yapmış oldukları yorumlara yapay zeka tarafından cevap verildiğinde mutlu olan bu kişiler, sanal etkileyenle daha fazla iletişim kurma ve arkadaş olma eğilimindedirler. Bu tip kullanıcılar için yapay zekanın onları fark edip, cevap vermesinin önemli olduğu söylenebilir.

Robotların, insanların ihtiyaçlarını ve beklentilerini anlayarak buna uyumlu olarak davranmalarının kabul görmeleri için önemli olduğuna dikkat çekilmektedir (Wirtz, ve diğerleri, 2018). Aynı şekilde robot kabulü için robotun insanların sosyal ve duygusal ihtiyaçlarını karşılamasının önemli olduğundan bahsedilmektedir (Stock \& Merkle, 2018). Ayrıca takipçilerin, sanal etkileyenin kurgulanmış yaşamındaki pek çok konuya hakim oldukları ve yaşanılan üzücü ya da sevindirici olaylarda da sanal fenomeni destekledikleri dikkat çekmektedir. Bunun yanı sıra sosyal medya kullanıcıları, ilgili sanal fenomenin kurgulanmış hayatında kendi yaşadıklarına benzer olaylar görmekte ve bu sayede sanal karaktere kendilerini daha yakın hissetmektedirler. Molin ve Nordgren tarafından yapılan araştırma sonuçları da elde edilen bulguları destekler niteliktedir. Araştırmaya göre, Lil Miquela'nın görünüşünün, yaşadığı olayların, davranışlarının ve karakter özelliklerinin takipçileriyle olan benzerliği, sosyal medya kullanıcılarıyla ilişki kurmasını kolaylaştırmaktadır (Molin \& Nordgren, 2019, s. 21). Bu bağlamda çalışma kapsamında elde edilen Tema 3, ilgili sanal karakter ile Instagram kullanıcıları arasında duygusal bir bağın oluştuğunu ortaya koymaktadır. Bu bulgu, özellikle sanal etkileyen pazarlamasının hedef kitlesi olan Z kuşağının, yapay zeka ile kolaylıkla duygusal bağ kurabilen bir nesil olduğu yönünde yorumlanabilir. Alanyazında sanal robotlara güven duyulmasını ve insanlar tarafından kabul edilmesini sağlayan en önemli faktörün, sosyal ve duygusal öğeler olduğu belirtilmektedir (Molin \& Nordgren, 2019, s. 7). Dolayısıyla sanal etkileyen ile takipçileri arasında kurulan duygusal bağın, yapay zekanın sosyal medyadaki kabulünde oldukça önemli bir rol oynadığı söylenebilir.

Tema 5 satın almaya yönlendirmede ise; sosyal medya kullanıcıları tarafından sıklıkla sanal etkileyenin görünüşüne, saçına ve giydiği markalı-markasız kıyafetlere iltifat edildiği tespit edilmiştir. Üstelik kıyafetlerin ya da eşyaların markalarının etiketlenmediği ticari olmayan paylaşımlara gelen yorumlarda bile ürünün markasını merak eden ve etiketlenmesini isteyen bir kesimin olduğu dikkat çekmektedir. Bu bağlamda, sanal etkileyenin paylaşımlarının Instagram kullanıcılarını etkilediği ve satın almaya yönlendirdiği anlaşılmaktadır. Araștırma kapsamında elde edilen Tema 5'in, sanal etkileyen pazarlamasında sıklıkla tartışmaya açılan "gerçekte var olmayan bir karakter, tıpkı gerçek bir insan etkileyen gibi tüketiciyi satın almaya yönlendirebilir mi?" sorusuna kaynak oluşturacağı düşünülmektedir. Walters'a göre başarılı bir etkileyen pazarlanması 
için etkileyen ve takipçi arasında duygusal bir bağ kurulması gerekmektedir, ancak sanal etkileyenin gerçek olmadığının bilinmesi bu insani bağı kurmayı zorlaştırmaktadır. Eğer bu bağ kurulamazsa tüketiciyi satın alma davranışına yönlendirmek oldukça zordur (Walter, 2019). Bu bağlamda, Tema 3 ve Tema 5'in birbirleriyle örüntülü olduğu söylenebilir. Tema 3'ün işaret ettiği gibi sanal etkileyen, takipçileriyle arasında duygusal bir bağ kurmayı başarmış, Tema 5'in de gösterdiği gibi bu duygusal bağ tüketicide etkilenme ve satın almaya yönelmeye dönüşmüștür.

Instagram takipçisinin kabullenme sürecinde önemli görülen Tema 4 gerçekliğini sorgulama olarak belirlenmiştir. Yorumlarda sıklıkla sanal fenomene yöneltilen 'gerçek bir insan mısın-yoksa robot musun?' soruları, kullanıcıların yapay zekanın gerçekliğini sorguladı̆̆ını göstermektedir. Brud şirketi tarafından Lil Miquela'nın gerçek olmayan bir karakter, bir yapay zeka olduğunun açıklanmasına rağmen sanal fenomeni gerçek bir insan olarak kabul edenlerin varlığı yorumlarda dikkat çekmektedir. Bu kişilerin sanal fenomenle gerçek bir birey gibi konuşmaya çalıştıkları ve tavsiyeler istedikleri gözlemlenmiştir. Ayrıca Miquela'nın sanal bir karakter olduğunu reddeden pek çok kişi, sanal fenomeni ilgi çekmek amaciyla Instagram filtrelerinden yararlanarak kendini dijital karakter gibi göstermeye çalışan bir insan olmakla suçlamaktadır. Bulgular, sanal etkileyenin insana olan yüksek benzerliğinden dolayı Instagram kullanıcılarının gerçek ve sanal ayrımını yapmakta zorlandıklarını göstermektedir. Ayrıca sözü edilen benzerliğin yanı sıra sanal etkileyenin paylaşımlarında gerçek insanlarla birlikte görülmesi, film galalarına gitmesi, festivallerde bulunması, gerçek markaların kıyafetlerini giymesi ve gerçekte var olan mekanlarda kendini etiketlemesi, Instagram kullanıcılarının zihnindeki gerçek ve sanal arasındaki çizgiyi bulanıklaştıran diğer önemli etkenlerdir. Sanal etkileyicinin açık bir şekilde kamuoyuna robot olarak tanıtılmasının yanı sıra insan izlenimi vermek adına gerçek insanlarla görülmesi, gerçek festivallere katılması sanal influencer ajansı olan Brud'un pazarlama stratejisinde karma gerçekliği (mixed reality) kullandığını göstermektedir (Booth, 2019). Karma gerçeklik, fiziksel gerçeklik ile sanal ve artırılmış gerçekliğin etkileşime geçmesi ya da bir araya gelmesi olarak tanımlanmaktadır (Can, 2017). Mostad, gün geçtikçe dijitalleşen dünyada gerçekle kurgunun ayrımının özellikle çocuklar için gittikçe zorlaştığına ve tehlikeli bir hal aldığına dikkat çekerek çocukların yapay zeka konusunda okulda ve aile içerisinde eğitilmesinin önemini vurgulamaktadır. Aynı şekilde Internet Matters'ın büyükelçisi ve psikolog Linda Papadopoulos'a göre, canlı verileri kullanarak gençleri kolaylıkla manipüle edebilme yeteneğine sahip olan sanal etkileyenler hakkında ailelerin çocuklarıyla konuşmaları ve çocuklarının eleştirel düşünmelerini sağlamaları gerekmektedir (Dodgson, 2019).

Söz konusu bu çalışmada takipçilerin yapay zeka ürünü sanal etkileyenleri kabullenmediğine yönelik bulgular da tespit edilmiștir. Nitekim Tema 2 negatif yaklaşımlar da bu duruma işaret etmektedir. Tema 2'de, bazı Instagram kullanıcılarının yapay zeka ürünü sanal etkileyenden rahatsız olduğu ve yaptığı işleri takdir etmediği tespit edilmiştir. Bu bulgu, bir kesim Instagram kullanıcısının, yapay zekanın sosyal medya üzerindeki varlığını onaylamadığı doğrultusunda yorumlanabilir. Özellikle bu tema altına giren yorumlarda bir yapay zekanın insan gibi davranmasının ve insana olan aşırı benzerliğinin kullanıcıları korkuttuğu ve sinirlendirdiği görülmektedir. Benzer şekilde yapılan bir çalışmada da Lil Miquela'nin insana benzerliğinin, tüketicilerin iletişime geçmesini kolaylaştırdığını ancak aşırı gerçekliğinin ise sosyal medya kullanıcılarını rahatsız ettiğini orta koymaktadır (Molin \& Nordgren, 2019). Bu durum, Masahiro Mori'nin Tekinsiz Vadi Teorisi (The Uncanny Valley Theory) ile ilişkilendirilebilir. Sanal 
karakterlerin ve robotların tasarımında, tasarımcılara katkı sağlamanın yanı sıra simüle edilen karakterlere, robotlara ya da avatarlara gelen olumsuz tepkileri açıllayabilmek için de kullanılan bu teori, Tekinsiz Vadi Etkisi ya da Hipotezi olarak da isimlendirilmektedir (Aylett, 2004; Fabri, Moore, \& Hobbs, 2004). İlgili teoriye göre bir robotun görünüşünün bir dereceye kadar insana benzer olması, tüketicide güven uyandırırken, robotun insana olan benzerliğinde aşırıya kaçılmasında ise tüketicide tekinsizlik duygusu ortaya çıkmaktadır. Çalışma kapsamında erişilen ilgili bulgunun aksine alanyazında, sanal etkileyenlerin insana olan benzerliğinin ve karakterinin gerçekliğinin sosyal medya kullanıcısının dikkatini daha çok çektiği ve güven duygusunu geliştirdiğini ortaya koyan çalışmalar da bulunmaktadır (Darner \& Arvidsson, 2019; Molin \& Nordgren, 2019). Dolayısıyla robotun insana olan benzerliğinin, bireyde ikna edici ve güven verici bir his uyandırması ile güvenilmez ve tekinsiz bir his uyandırması arasında ince bir çizgi bulunduğu söylenebilir. Buna ek olarak, yorumlarda sanal etkileyeni insan olarak benimsemeyen takipçilere tepki gösteren bir kesimin olduğu da dikkat çekmektedir. Bu kişiler, başkaları tarafından yapay zekanın yaptığı işlerin beğenilmesine, merak edilmesine, takip edilmesine tepki göstermekte ve bu durama anlam verememektedirler.

Sonuç olarak, yapılan niceliksel içerik analizi sonucunda, 650 takipçi yorumunun \% 69,4'ünün yapay zekaya yönelik olumlu yaklaşım gösterdiği tespit edilmiștir. Tema 1 pozitif yaklaşım-kabullenme de bu sonucu desteklemektedir. Bunun yanı sıra Tema 2'nin işaret ettiği negatif yaklaşımın $(\% 9,2)$ olduğu da göz ardı edilmemesi gerekmektedir. Yapay zekanın gerçekliğini sorgulayan takipçilerin nötr düşüncede $(\% 21,4)$ olması da araștırma kapsamında önemli bir bulgu olarak görülebilir (bkz. Tablo 2). Dolayısıyla yenilik olarak görülen yapay zeka ürünü sanal etkileyenin, araştırma özelinde Instagram kullanıcıları tarafından çoğunlukla kabullenildiği görülmektedir. Çalışma kapsamında ortaya çıkan bu bulgular sosyal medya kullanıcılarının, teknoloji şirketleri tarafından yaratılan ve yönetilen sanal etkileyenler tarafından çeşitli çıkarlar doğrultusunda manipüle edilebileceğini de göstermektedir. Bu bağlamda, gelecekte sosyal medya platformlarında sanal etkileyen gibi yapay zeka uygulamalarının kullanımının artacağ düşünüldügünde, yeni medya okuryazarlığı içerisine yapay zeka farkındalık eğitimlerinin de eklenmesi gerektiğinin önemli olduğu görülmektedir. Bu sayede bireylerin gerçek ile sanal arasındaki ayrımı yapabilecekleri ve eleștirel düşünebilecekleri öngörülmektedir.

\section{Kaynakça}

Agarwal, R., Ahuja, M., Carter, P., \& Gans, M. (1998, September 15). Early and late adopters of it innovations: Extensions to innovation diffusion theory. Researchgate:https:// www.researchgate.net/publication/228395578_Early_and_late_adopters_of_IT_ innovations_Extensions_to_innovation_diffusion_theory adresinden alındı

Aslan, E. (2014). Yabancı dil öğretiminde robot öğretmenler. Ondokuz Mayıs Üniversitesi Eğitim Fakültesi Dergisi, 33(1), s. 15-26.

Atalay, M., \& Çelik, E. (2017, Aralık). Büyük veri analizinde yapay zeka ve makine öğrenmesi. Mehmet Akif Ersoy Üniversitesi Sosyal Bilimler Enstitüsü Dergisi, 9(22), s. $155-172$.

Aylett, R. (2004, May). Agents and affect: Why embodied agents need affective systems. Researchgate:https://www.researchgate.net/publication/220842018_Agents_ and_Affect_Why_Embodied_Agents_Need_Affective_Systems adresinden alındı 
Baklanov, N. (2019, November 14). The top Instagram virtual influencers in 2019. Hype - Journal: https://hypeauditor.com/blog/the-top-instagram-virtual-influencersin-2019/ adresinden alınd 1

Barth, T., \& Arnold, E. (1999, December 1). Artificial intelligence and administrative discretion- implications for public administration. American Review of Public Administration, 29(4), s. 332-351.

Başer, D. (2018, Haziran). HBR Türkiye olarak liderlere yapay zekâ çağında pazarlamayı sorduk. (H. B. Türkiye, Röportaj Yapan)

Bendoni, W., \& Danielian, F. (2019, July). The future of Influencer marketıng in the digital age of virtual influencers. Global Fashion Management Conference: https://doi. org/10.15444/GFMC2019.06.02.01 adresinden alındı

Berger, J. (2005). Perceived consequences of adopting the internet into adult literacy and basic education classrooms. Adult Basic Education, 15(2), s. 103-121.

Bingöl, Ç. (2018, Haziran 27). Sanal modeller geliyor. Harper's Bazaar Türkiye: https:// www.harpersbazaar.com.tr/moda/2018/06/27/sanal-modeller-geliyor adresinden alındı

Booth, R. (2019, November 4). Fake online influencers a danger to children, say campaigners. Support the Guardian: https://www.theguardian.com/media/2019/ nov/04/fake-online-influencers-a-danger-to-children-say-campaigners adresinden alındı

Bozüyük, T., Yağcı, C., Gökçe, İ., \& Akar, G. (2005). Yapay zeka teknolojilerinin endüstrideki uygulamaları. Isparta Uygulamalı Bilimler Üniversitesi Teknoloji Fakültesi: https://teknoloji.isparta.edu.tr/assets/uploads/sites/134/files/is-yeri-egitimi-6hafta-odev-notu-08052020.pdf adresinden alındı

Büyükdumlu, Ş. (2019, Temmuz 5). Instagram'ın ilginç sanal kullanıcısı. Pazarlamasyon: https://pazarlamasyon.com/instagramin-ilginc-sanal-kullanicisi/ adresinden alındı

Cameron, N. (2017, May 3). Pfizer Austrailia adopts AI powered digital analyst tool sales marketing decision making. CMO FROM IDG: https://www.cmo.com.au/ article/618608/pfizer-australia-adopts-ai-powered-digital-analyst-tool-salesmarketing-decision-making/\#: :text=Pfizer\%20Australia\%20is\%20rolling\%20 out,sales\%20and\%20marketing\%20decision\%20making.\&text=Complexica $\% 20$ chief $\% 20$ scientist adresinden alındı

Can, A. (2017, Kasım 9). Karma gerçeklik nedir? Ne işimize yarar? Medium: https://medium.com/dijitaldonem/karma-ger\%C3\%A7eklik-nedir-nei\%CC\%87\%C5\%9Fimize-yarar-8389a66bc6a7 adresinden alındı

Çin〉de bir robot. (2017, Kasım 19). basnews: https://www.basnews.com/tr/ babat/393905 adresinden alındı

Darner, A., \& Arvidsson, N. (2019, June). Virtual influencers - anonymous celebrities on A qualitative study of virtual influencers, a new phenomenon on social media. http:// hj.diva-portal.org/smash/get/diva2:1335875/FULLTEXT01.pdf adresinden alındı 
Dodgson, L. (2019, November 8). CGI influencers could be exploiting children and their parents should be aware, internet safety campaigners have warned. Insider: https://www.insider.com/children-can-be-easily-manipulated-cgi-instagraminfluencers-2019-11 adresinden alındı

Durakcan, Y. C. (2015, Haziran 22). Yapay zekanın kısa tarihçesi. Bilim Fili: https:// bilimfili.com/yapay-zekanin-kisa-tarihcesi adresinden alındı

Fabri, M., Moore, D., \& Hobbs, D. (2004, February 5). Mediating the expression of emotion in educational collaborative virtual environments: An experimental study. Virtual Reality, 7, s. 66-81. doi: 10.1007/s10055-003-0116-7

Fraenkel, J. R., \& Wallen, N. E. (2006). How to design and evaluate research in education (6. b.). New York: McGraw-Hill International Edition.

Harding, S. (2019, April 10). The impact of virtual influencers on today's ever-changing media landscape. Talking Influence Talking Trends in Influencer Marketing: https://talkinginfluence.com/2019/04/10/the-impact-of-virtual-influencers-ontodays-ever-changing-media-landscape/ adresinden alındı

Hurlay, M., \& Wallace, W. (1986, November). Expert systems as decision aids for public managers: An assessment of the technology. Wiley on behalf of the American Society for Public Administration, 46, s. 563-571.

Jacob, V., Moore, J., \& Whinston, A. (1988). Artificial intelligence and the management science practitioner: rational choice and artificial intelligence. Interfaces, 18(4), s. 24-35.

Jain, R. (2017, July 7). Creative robots? Google's deepmind artificial intelligence is getting Imagination. International Business Times: https://www.ibtimes.com/creativerobots-googles-deepmind-artificial-intelligence-getting-imagination-2571174 adresinden alındı

Kayıkçı, M. Y., \& Bozkurt, A. K. (2018). Dijital çağda z ve alpha kuşağı, yapay zeka uygulamaları ve turizme yansımaları. Sosyal Bilimler Metinleri(1), s. 54-64.

Keleş, A., Keleş, A., \& Akçetin, E. (2017). Pazarlama alanında yapay zeka kullanım potansiyeli ve akıllı karar destek sistemleri. International Periodical for the Languages, Literature and History of Turkish or Turkic, 12(11), s. 109-124. doi:http://dx.doi.org/10.7827/TurkishStudies.12022

Kocabaş, Ș. (2015). Yapay zeka araştırma ve uygulama alanları. Docplayer: https:// docplayer.biz.tr/3313838-Yapay-zeka-arastirma-ve-uygulama-alanlari.html adresinden alındı

Köroğlu, Y. (2017). Yapay zeka'nın teorik ve pratik sınırları. VI. Evrim, Bilim, ve Eğitim Sempozyumu. İstanbul. https://www.cmpe.boun.edu.tr/ yavuz.koroglu/ publications/EBES17.pdf adresinden alındı

Köse, H. (2017, Ocak-Mart). Robot işaret dili öğretmeni. İstanbul Teknik Üniversitesi Vakfı Dergisi(75), s. 31-35.

Kuşçu, E. (2015, Mayıs 5). Çeviride yapay zeka uygulamaları. Atatürk Üniversitesi Kazım Karabekir Eğitim Fakültesi Dergisi, 0(30), s. 45-58. 
Küçükvardar, M. (2015). Bilişim devrimi: Reel gerçekliğin sanal gerçekliğe dönüşümü. YÖK Ulusal Tez Merkezi: https://tez.yok.gov.tr/UlusalTezMerkezi/tezSorguSonucYeni. jsp adresinden alındı

Lewis, T., \& Writer, S. (2014, December 4). A brief history of artificial intelligence. Live Science: https://www.livescience.com/49007-history-of-artificial-intelligence. html adresinden alındı

McMillan, J. H. (2000). Educational research: Fundamentals for the consumer (3. b.). New York: Longman.

Mijwil, M. M. (2015, April). History of artificial intelligence. Researchgate: https://www. researchgate.net/publication/322234922_History_of_Artificial_Intelligence adresinden alındı

Molin, V., \& Nordgren, S. (2019, June). Uppsala university Publications. Uppsala University: http://uu.diva-portal.org/smash/get/diva2:1334486/FULLTEXT01. pdf adresinden alındı

Onay, A., \& Övür, A. (2018, Eylül). Yapay zeka örneği olarak Black Mirror dizisi metal kafa bölümünün incelenmesi. Yeni Medya Elektronik Dergi-eJNM, 2(3), s. 121-135. doi:10.17932/IAU.EJNM.25480200.2018.2/3.121-135

O’Regan, G. (2012). A brief history of computing. London: Springer-Verlag.

Önder, M., \& Saygılı, H. (2018, Aralık). Yapay zekâ ve kamu yönetimine yansımaları. Türk İdare Dergisi, 90(487), s. 629-668.

Özel, M. (2016, Kasım 12). Süperzeka'ya giden yol çok yakınımızda! evrim ağacı: https:// evrimagaci.org/superzekaya-giden-yol-cok-yakinimizda-444 adresinden alındı

Öztemel, E. (2012). Yapay sinir ağları. İstanbul: Papatya Yayıncılık.

Öztürk, K., \& Şahin, M. E. (2018, Aralık 30). Yapay sinir ağları ve yapay zeka'ya genel bir bakış. Takvim-i Vekayi, 6(2), s. 25-36.

Pirim, H. (2006). Yapay zeka. Journal of Yasar University, 1(1), s. 81-93.

Power, D. (2003, Nowember 9). How can behavioral models be used for decision support? DSS News, 4(23).

Rogers, E. M. (2003). Diffusion of innovation (5. b.). New York: Free Press.

Russell, S. J., \& Norvig, P. (2003). Artificial Intelligence A Modern approach. New Jersey: Prentice Hall.

Saplığlu, K., \& Uzundurukan, S. (2019, Mart 15). Bilimsel çalışmalarda kullanılan bazı yapay zeka uygulamalarının ve trendlerinin incelenmesi. Dicle Üniversitesi Mühendislik Fakültesi Mühendislik Dergisi, 10(1), s. 249-262.

Shortliffe, E. (1977, October 5). Mycin: A knowledge-based computer program applied to infectious diseases. Proc Annu Symp Comput Appl Med Care, s. 66-69.

Sokolov, M. (2019, December 5). Virtual influencer trends: an overview of the industry. The Drum: https://www.thedrum.com/opinion/2019/12/05/virtual-influencertrends-overview-the-industry adresinden alındı

Sor'un. (2019). Dijital pazarlamada yapay zekanın kullanım alanları. SOR'UN blog: https://www.sorun.com.tr/blog/dijital-pazarlamada-yapay-zekanin-kullanimalanlari adresinden alındı 
Soylu, E. (2018, Aralık 19). Yapay zeka pazarlama örnekleri. Blogager: https://blog. adgager.com/yapay-zeka-pazarlama-ornekleri/ adresinden alındı

Stock, R. M., \& Merkle, M. (2018). Can humanoid service robots perform better than service employees? A comparison of innovative behavior cues. Proceedings of the 51st Hawaii International Conference on System Sciences I, (s. 1056-1065). Waikoloa Village. doi:10.24251/HICSS.2018.133

Time. (2018, June 30). The 25 most influential people on the internet. Time: https://time. com/5324130/most-influential-internet/ adresinden alındı

Topal, Ç. (2017, Aralık 27). Alan Turing'in toplumbilimsel düşünü: Toplumsal bir düş olarak yapay zeka. DTCF Dergisi, 57(2), s. 1340-1364.

Vashisht, M. (2017). How is artificial intelligence changing the public sector? İSHIR Excellence Delivered: https://www.ishir.com/blog/4662/artificial-intelligencechanging-public-sector.htm\#: :text=AI\%20systems $\% 20$ can $\% 20$ pull $\% 20$ data,prioritize $\% 20$ tasks\%20and\%20allocate\%20resources. adresinden alındı

Virtual influencers. (2019). kolsquare: https://www.kolsquare.com/en/blog/virtualinfluencer adresinden alınd

Walter, T. (2019, February 25). How CGI influencers will impact the channel in 2019. talking influence talking trends in influencer marketing: https://talkinginfluence. com/2019/02/25/how-cgi-influencers-will-impact-channel-2019/ adresinden alındı

Wirtz, J., Patterson, P., Kunz, W., Gruber, T., Lu, V. N., Paluch, S., \& Martins, A. (2018, October 15). Brave new world: service robots in the frontline. Journal of Service Management, 29(5), s. 907-931.

Yalçın, F. G. (2019, Şubat 28). Influencer Marketing'in sanal yolculuğu. digitalage: https:// digitalage.com.tr/influencer-marketingin-sanal-yolculugu/ adresinden alındı

Yıldırım, A., \& Şimşek, H. (2013). Sosyal bilimlerde nitel araştırma yöntemleri (9. b.). Ankara: Seçkin.

Yıldız, M., \& Yıldırım, B. F. (2018, Ocak 1). Yapay zekâ ve robotik sistemlerin kütüphanecilik mesleğine olan etkileri. Türk Kütüphaneciliği, 32(1), s. 26-32. 


\title{
A Study on the Adoption of the Artificial Intelligence Product Virtual Influencer on Instagram in the Context of the Spread of Innovations by Followers
}

\author{
Sezen Garip (Ph.D. Student) \\ Pelinsu İnceli (Ph.D. Student)
}

\section{Extended Abstract}

The concept of artificial intelligence is defined as the transfer of human behaviors to machines. This transfer is carried out through computer programs and algorithms (Mijwil, 2015, s. 3). Alan Turing opened the intelligence of machines to discussion in his article, "Computing Machinery and Intelligence" by asking "Can Machines Think?" (Aslan, 2014; Kuşçu, 2015; Lewis \& Writer, 2014). The concept of artificial intelligence, which emerged in the 1950s, has become an important tool in information and communication technologies in the 2000s (Keleş, Keleş, \& Akçetin, 2017). The most important goal in the development of artificial intelligence applications is to make human life easier. Nowadays, people coming together on digital platforms and meeting their needs and motivations on these digital platforms have also paved the way for the development of artificial intelligence applications. One of these applications is the virtual influencers on Instagram. The difference from digital influencers is that virtual influencers are fictional characters.

Artificial intelligence product virtual influencers have been specially designed for the Z generation (Yalçın, 2019). The first example of those who influence the artificial intelligence product virtual on Instagram is Lil Miquela, which Brud established as half Spanish and half Brazilian (Bendoni \& Danielian, 2019, s. 606). Looking like a real woman, Lil Miquela collaborates with famous brands. It communicates with its Instagram followers and markets the products of the brands. In this case, it is possible to see the artificial intelligence product virtual influencer as an innovation on the Instagram platform. Theory of diffusion of innovations; It tries to define the acceptance and rejection processes of innovation in the social system (Agarwal, Ahuja, Carter, \& Gans, 1998). In this study, in line with the theory of diffusion of innovations, it was aimed to make an examination for the acceptance of the artificial intelligence product by Instagram users. For this purpose, answers to the following research questions were sought: How do Instagram users perceive the shares of the artificial intelligence product of the virtual influencer? What is the direction of the comments made by Instagram users who follow the artificial intelligence product virtual influencer? This research involves qualitative research processes. It is structured according to the case study, one of the qualitative research designs. When the literature is examined, no research has been found within the scope of the subject. In this case, it reveals the importance of this study.

In accordance with the purpose of the study, criterion sampling was chosen from purposeful sampling methods. The first of the criteria determined is that the Instagram account belongs to artificial intelligence. The other criterion is having enough shares and follower comments to analyze in the Instagram account. The Instagram account named "Lilmiquela" was included in the sample in line with the determined criteria. User comments under the posts made between November 4-10 and November 18-24 in 2019 
were collected on Lilmiquela Instagram account. 13 posts were shared between these dates. A limitation has been made while collecting comments from these posts. Only 50 comments were included in the analysis. A total of 650 user reviews were reviewed. The obtained data were analyzed by qualitative (thematic) content analysis and descriptive content analysis method. Qualitative content analysis was done separately by the researchers without using a computer program. Then the obtained codes, categories and themes were compared. Common results have been evaluated and a consensus has been reached. At the same time, quantitative content analysis based on qualitative data was also performed. SPSS program was used in quantitative content analysis. The variables searched in the comments are coded as yes (1) and not (0). The shares are coded as P1, P2, P3... and their dates are included.

Five themes were determined as a result of the data analysis: positive approach acceptance, negative approach, emotional approach, questioning the reality and directing to purchase. The theme of positive approach - acceptance focuses on the excitement, interest and curiosity of Instagram followers about the posts made by artificial intelligence. As a result of the quantitative content analysis, it was determined that $69.4 \%$ of 650 follower comments showed a positive approach to artificial intelligence. This result also supports the theme 1 positive approach-acceptance result. It should not be overlooked that there is a negative approach (9.2\%) indicated by Theme 2 . The negative attitudes theme deals with the discomfort felt by other people accepting the robot that behaves like a human. The Emotional Approach theme indicates that followers want to be friends with AI. The theme of questioning its reality focuses on followers' confusion as to whether the robot is a human or a robot. In other words, followers take part in neutral thinking by questioning its reality. The fact that the followers questioning the reality of artificial intelligence are in neutral thinking (21.4\%) can be seen as an important finding within the scope of the study. Finally, the theme of directing to purchasing focuses on the fact that the product promotions made by artificial intelligence in cooperation with brands affect the followers and arouse the desire to buy. As a result, it can be said that the artificial intelligence product, which is seen as an innovation, is accepted by Instagram users within the scope of the research.

Keywords: Communication, Artificial Intelligence, Virtual Influencer, Diffusion of Innovations, Instagram.

Bu makale intihal tespit yazılımlarıyla taranmıştır. Intihal tespit edilmemiştir.

This article has been scanned by plagiarism detection softwares. No plagiarism detected.

Bu çalışmada "Yükseköğretim Kurumları Bilimsel Araştırma ve Yayın Etiği Yönergesi” kapsamında uyulması belirtilen kurallara uyulmuştur.

In this study, the rules stated in the "Higher Education Institutions Scientific Research and Publication Ethics Directive" were followed.

Yazarların çalışmadaki katkı oranları eşittir.

The authors' contribution rates in the study are equal.

Çalışma kapsamında herhangi bir kurum veya kişi ile çıkar çatışması bulunmamaktadır.

There is no conflict of interest with any institution or person within the scope of the study. 